\title{
Flyg min sång kring Bältens strand
}

Svenska krigs- och segerdikter 1813

Den 5 OKTOBER I8II FÖLL DOMEN på tre års fängelse på Vaxholms fästning för tidningsmannen Adolf Regnér (I786-I852). Hans brott var en artikel i den egna tidningen Allmän Politisk Journal. I dess tredje nummer den I4 september I8II offentliggjorde han nämligen artikeln ”Om möjligheten af Finlands återförening med Swerige?”, i vilken han i ganska allmänna ordalag diskuterar huruvida olika politiska kombinationer ute bland Europas ledande stater på längre sikt skulle kunna göra det möjligt för Sverige att återfå Finland. Ett möjligt erövringskrig diskuteras inte, det är fredliga medel som är föremål för Regnérs analyser. Men det räckte för att utlösa intensiva motåtgärder från myndigheternas sida. Ärendet expedierades med största möjliga skyndsamhet. Det förlöpte blott 22 dagar mellan åtal och dom i kämnärsrätten i Stockholm. Man får tänka sig att kronprins Karl Johan önskade att snabbt statuera exempel för att få slut på offentlig diskussion om svenska planer på återerövring av Finland. Kronprinsens utrikespolitiska överväganden hade tagit en riktning som inte borde störas av oönskade opinionsyttringar. Efter det att I8I2 års tryckfrihetsförordning införts, omöjliggjordes offentlig diskussion om utrikespolitiska spörsmål som inte överensstämde med regeringens linje, särskilt i Finlandsfrågan. Diktare som Esaias Tegnér, Pehr Henrik Ling och andra hade höjt rösten och krävt revansch för att återta det förlorade Finland. Efter TF I8I2 och affären Regnér tystnade diktarnas opinionsbildande lyriska inlägg i frågan för att återkomma först långt senare. ${ }^{1}$

I. Krister Nordberg, Såret vill blöda ännu. Finland i svensk dikt $1808-1848$, Skrifter utgivna av Svenska litteratursällskapet i Finland (SSLS) 717, Helsingfors: SLS 2009, s. 92-97. 
Kronprins Karl Johan var fullt medveten om att många svenskar drömde om att Finland snarast återbördades till moderlandet. Men han menade att Sverige ifall landet återtog Finland vart tionde år skulle få utkämpa blodiga strider med Ryssland. ${ }^{2}$ Kronprinsens intresse visade sig snart vara $\mathrm{i}$ huvudsak inriktat på Norge. Sedan han under våren I8II hade laborerat med olika kombinationer i stormaktspolitiken för att uppnå målet, förde han en vänskapspolitik med den gamla fienden Ryssland för att med dess stöd erövra Norge eller ansluta landet till Sverige. Diplomaten och greven Carl Löwenhielm sändes till S:t Petersburg. Där undertecknades den 5 april I8ı2 en traktat i vilken båda länderna garanterade varandras besittningar. Sverige skulle avstå från att försöka återta Finland och Ryssland skulle hjälpa Sverige att erhålla Norge. Mot den bakgrunden är det lätt att förstå domen mot Adolf Regnér ett halvår tidigare. Behovet att både litterärt och publicistiskt dämpa opinionsyttringar i Finlandsfrågan var starkare när inriktningen på Norge hade börjat ta form.

I januari I8ı2 hade Frankrike ockuperat Svenska Pommern. Svenska ämbetsmän byttes ut mot franska, svensk egendom konfiskerades och officerare och soldater togs som krigsfångar och sändes till Frankrike. I Sverige reagerade man kraftigt och sympatierna för Frankrike och Napoleon svalnade. Händelsen lade grunden för "en nyorientering av Sveriges utrikespolitik", skriver historikern Jörgen Weibull. ${ }^{3}$

I augusti detta år sammanträffade kronprins Karl Johan och kejsar Alexander I i Åbo där överenskommelsen i S:t Petersburg med tillägg undertecknades, med fortsatt hänsynstagande till sekretess. ${ }^{4}$ Den nya linjen i svensk utrikespolitik, den som skulle kallas I8I2 års politik, var därmed etablerad. Sverige skulle med hjälp av Ryssland erövra Norge eller ansluta landet till Sverige genom att besegra eller förhandla med Danmark. Det skulle visa sig att Sverige först skulle ingå i alliansen

2. Nils Erik Villstrand, Furstar och folk i Åbo I812, Skrifter utgivna av Svenska litteratursällskapet i Finland (SSLS) 768, Helsingfors: SLS / Stockholm: Atlantis 20I2, s. 24; Torvald T-son Höjer, Carl XIV Johan. Kronprinstiden, Stockholm: P. A. Norstedt \& Söners förlag I943, s. II9.

3. Jörgen Weibull, Carl Johan och Norge I8ro-I8I4. Unionsplanerna och deras förverkligande, Lund: Gleerups / Oslo: Universitetsforlaget 1957, s. 59.

4. Om Karl Johans resa till mötet i Åbo 27-31/8 I8I2 som en väl bevarad hemlighet, se Villstrand, Furstar och folk $i$ Åbo I8I2, s. 73-76. 
mellan Ryssland, Österrike och Preussen och medverka i kriget mot Napoleon i Tyskland.

Vid staden Leipzig stod det avgörande fältslaget mellan Napoleons Frankrike och den nämnda alliansen, ett fältslag som fick beteckningen "den stora folkslaktningen". Det var det största fältslaget i Europa före första världskriget och början till slutet för Napoleons herravälde i Europa. Segrarna i fältslagen i Tyskland, och särskilt det i Leipzig, kom att innebära något av en revansch för svenskarna. En känsla av att man återtagit den förlorade hedern från nederlagens tid och förlusten av Finland i 1808-I809 års krig spred sig i landet.

Författare följer händelsernas gång med dikter och sånger för sina landsmän i fält, för landsmännens nöje och underhållning samt för patriotisk uppbyggelse. För hemmafrontens svenskar trycktes och utgavs samma dikter och sånger samtidigt och spreds som små trycksaker. De fungerade som sammanhållande kraft mellan militären på slagfälten och de hemmavarande anhöriga och andra landsmän.

Ett syfte med denna studie, som i tid omfattar perioden maj till och med november I8I3, är att låta några diktarröster skildra, belysa och tolka i dikter och sånger i olika medier den nya mentala atmosfär som skapades av händelserna i Tyskland. Denna nya politiska diktning står i kontrast till den diktning som svenskarna kunde ta del av i samband med det några år tidigare avslutade kriget. ${ }^{5}$ En anda av kamplust och återfunnen optimism speglas i krigsdikterna, och en känsla av lättnad och glädje, för att inte säga triumf, genomsyrar segerdikterna efter framgångarna i Tyskland. Ett annat syfte med studien är att erinra om diktens och sångens betydelse i ett samhälle i tider av oro, krig och förluster av människoliv.

\section{PÅ SLAGFÄLTEN}

Under vintern I8I3 förberedde sig svensk militär för överskeppning till Svenska Pommern. ${ }^{6}$ Kronprins Karl Johan anslöt sig den I8 maj i Stralsund där de svenska trupperna om 30 ooo man samlades. Under

5. Nordberg, Såret vill blöda ännu, s. 15-54.

6. Om diktning under förberedelsetiden våren I813, se Nordberg, Såret vill blöda ännu, s. 99-IO4. 


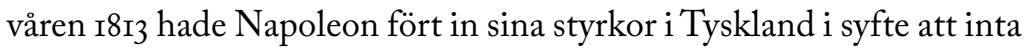
Berlin och besegra Preussen. Sedan den diplomatiska bilden mellan de allierade makterna, Preussen, Ryssland och Österrike, hade klarnat var Sverige i augusti med i kriget på allvar. $\mathrm{Nu}$ var tiden inne för en uppgörelse mellan de allierade och Frankrike vilken man hoppades skulle göra slut på de många åren av krig, och leda till att fred i Europa skulle kunna uppnås.

Ett fältslag utkämpades i Grossbeeren utanför Berlin den 23 augusti där nordarmén under Karl Johans ledning segrade. I detta slag var främst preussarna aktiva. Ett andra slag utkämpades vid byn Dennewitz $68 \mathrm{~km}$ sydväst om Berlin den 6 september. De allierade segrade. Svenskarna led små förluster medan Preussen gjorde stora. Det avgörande fältslaget utkämpades några veckor senare, den I6-19 oktober vid Leipzig. Här krossades Napoleons trupper, vilket innebar början till slutet för Napoleons dominans i europeisk politik. ${ }^{7}$

Därefter förde Karl Johan de svenska trupperna, inte västerut mot Holland som de allierade begärde, utan norrut. Den 5 december besatte svenskarna Lübeck och ett par dagar senare besegrades en dansk styrka i Bornhöft i Holstein. Därefter intog de Kiel medan danskarna förflyttade sig norrut. Sedan rådde vapenvila mellan Sverige och Danmark till dess att freden i Kiel undertecknats den I4 januari I8I4.

I Kiel, och strax därpå i Örebro, trycktes ett litet häfte i frakturstil med den långa titeln Tre Nya Krigs-Wisor, Den Första: En Afskedssång af en ung Bewärings-man, som går ut i fält. Den Andra: En Fält-Wisa efter landstigningen i Pommern. Den Tredje: En Segersång öfwer slaget vid Dennewitz eller Jüterbock. Alla Tre sjungas på sina egna hurtiga och behageliga Melodier. Inget författarnamn anges, vilket var vanligt i trycksaker av det här slaget. ${ }^{8}$

7. I slagen vid Lützen, Dresden och Bautzen segrade fransmännen under Napoleons ledning i augusti I8I3 för att nämna ytterligare några av de åtta slagen i den blodiga serien av fältslag hösten I8I3.

8. Tre Nya Krigs-Wisor, Den Första: En Afskedssång af en ung Bewärings-man, som går ut i fält. Den Andra: En Fält-Wisa efter landstigningen i Pommern. Den Tredje: En Segersång öfwer slaget vid Dennewitz eller Jüterbock. Alla Tre sjungas på sina egna hurtiga och behageliga Melodier, Kiel: Kongl. Fält-Tryckeriet 1813. Även tryckt i Örebro: N. M. Lindh I8ı3. Örebroupplagan har en tryckt anmärkning: "Äro nyss komna ifrån: Tyskland.” Den första och tredje visan finns tryckta i en upplaga från Jönköping: Lundströmska Tryckeriet I813, och såldes till ett pris av I skilling 
Bort, plog och spade, ur min hand!

Kom swärd och bajonett!

Jag går att slåss för Kung och Land,

Och skaffa fred och rätt.

Den första av de tre dikterna inleds med ett bestämt utrop av diktens beväringsman, en hurtig yngling med patriotisk entusiasm, en bondesoldat som kunde kännas igen av de tänkta läsarna i fält. Men också av hemmafrontens fäder och mödrar eftersom visan samtidigt salufördes i Sverige för en billig penning. I andra strofen tecknar beväringsmannen sig själv:

Jag köper ej en annans blod,

Mitt eget wågar jag.

Är jag för ung? Har jag ej mod?

Försök, om jag är swag!

Han går själv ut i strid för sitt land, han lejer inte en ersättare för pengar. Han är ung, han utmanar sitt öde. Snart följer själva avskedsscenen och den gode sonens omtanke om föräldrarna:

Farwäl, min Far! Wälsigna mig

Med ett par Herrans ord,

Och sen förgät, att det är krig:

Blott sköt i lugn er jord.

Gråt ej, min Mor! War nöjd, ni har

En stridsman åt ert land.

Det är på ärans wäg, jag far,

Och under Herrans hand.

banco. Ett tredje exempel: Trenne Nya Bewärings- och Krigs-Sånger, Gefle: Carl G. Sundqwist I8I4; Om krigsdiktning under Gustav III:s krig, se Henrika Tandefelt, "Dikten i krigets tjänst", Johan Wrede (utg.), Finlands svenska litteraturhistoria. Första delen: Aren I400-I900, Helsingfors: Svenska litteratursällskapet i Finland / Stockholm: Atlantis 1999, s. I89-I9I. 
Den folkligt troskyldiga gudstron går som en röd tråd genom dikten, en gudstro och en tröst i den grymma verklighet då en yngling lämnar hemmet för att gå ut i krig där allt kan hända.

Will Gud, så ser jag er ännu,

Och blir er ålders tröst

Och för min plog, så flinkt som nu,

Med ärren på mitt bröst.

Självfallet finns en flicka i ynglingens tankar, alldeles särskilt om han inte kommer tillbaka. Men hans käcka sinnesstämning, i vilken äventyrslusten lever sida vid sida med gudsförtröstan, lämnar honom inte:

Min flicka, som till kyrkan går,

Och ser den raska tropp,

Men ser ej mig, skall med en tår

Åt himlen sucka opp.

Der hoppas hon, i ewig fröjd,

Hos Gud få råka mig;

Och sjunger, med hans wägar nöjd:

O Gud! wi lofwe dig!

Strofen därpå, den näst sista, uttrycker ett sista farväl till "hyddan” där hemma som känns för "trång". Han vill ut i fält och känna friheten. Visans sista strof tolkar förväntningarna inför kommande strider:

Dit will jag, öfwer haf och land,

Der man i elden är!

Der will jag stå, med swärd i hand,

Och döden se helt när.

Vem är då författaren till vissamlingens tre dikter eller sångtexter? Hade de en eller flera författare? Utgivare av trycksaker av det här slaget lade självsvåldigt in texter från olika häften i nya tryck, och de som här förekommer återfinns även i andra sånghäften tryckta $i$ Kiel och på olika orter i Sverige. Kungliga Bibliotekets exemplar av 
Tre Nya Krigs-Wisor har ett par blyertsanteckningar längst ned på titelbladet: "I. Livijn skrifver till Hammarsköld att författaren var Hartmannsdorff. 2. Är dock af Franzén, tryckta i hans skrifter."

Clas Livijn (I78I-I844), som anteckningen syftar på, var författare och jurist, och han deltog i kriget som auditör, juridisk civilmilitär tjänsteman. Han var flitig brevskrivare och höll kontakten med hemlandet och vännerna Lorenzo Hammarsköld (I785-1827) och Leonhard Fredrik Rääf (I786-I872). I ett brev till den förre, avsänt från Visé i Belgien den 3I mars I8I4, skriver Livijn:

I afseende på de i Tyskland tryckta visorna kan jag försäkra dig, att de äro ingalunda af mig, men deremot har jag starka misstankar på brodren August $\mathrm{H}$ (artmansdorff), genom hvars försorg omkring I,००० exemplar blifvit upplagda och utdelade, ehuru han gör allt för att få folket att tro det Fransén är den sannskyldige. ${ }^{9}$

Författarskapet har alltså diskuterats, men Gösta Lundström har av allt att döma sagt sista ordet i sin bok Frans Michael Franzén. Liv och diktning under Kumlatiden (1947) med hjälp av ett brev från Franzén till landshövding von Rosenstein skrivet redan den 26 november I8r3, i vilket Franzén vidgår sitt författarskap till de tre visorna. ${ }^{10}$

9. Clas Livijn, Breffrån fälttågen i Tyskland och Norge I8I3 och I8I4, utgifna med en inledning af Johan Mortensen, Stockholm: Aktiebolaget Ljus 1909, s. I54. I en not till textstället fastslår utgivaren att författaren är Frans Michael Franzén. Han noterar att Franzén tog in dikterna i sina Skaldestycken, i828-upplagan, Frans M. Franzén, Skaldestycken. Andra bandet, Örebro: N.M. Lindh I828, s.307-316, men nämner inte att det gäller blott två av dem, den första och den tredje.

ıo. Gösta Lundström berör attribueringen i sin bok Frans Michael Franzén. Liv och diktning under Kumlatiden, Göteborg: Gumperts förlag 1947, s. 42. Här hänvisar Lundström till ett brev daterat 26/II I8I3 från Franzén till Nils von Rosenstein (I752-I824), som medföljer ett exemplar av Tre Nya Krigs-Wisor i vilket han ber Rosenstein att ej avslöja författarens identitet. Lundström tar Franzéns utsaga som bevis på att han "erkänner alla tre visorna som sina". Detta gäller alltså även "Fältvisan" vars avvikande poetiska stil kan tyckas sätta saken i fråga. Lundström tror att Franzén ansåg att den inte var god nog när han avstod från att ta med den i Skaldestycken II. De hårda, för att inte säga hatiska orden om Napoleon kanske inte heller var helt förenliga med hans dagliga värv som kyrkoherde i Klara församling i Stockholm 1828 med en biskopsutnämning i sikte några år framåt i tiden. Se vidare Nordberg, Säret vill blöda ännu, s. 67-74, om Franzéns politiska diktning i samband med rikssprängningen. August von Hartmansdorff (I792-I856) var politiker och 
Frans Michael Franzén (1772-1847) var vid den här tiden sedan ett par år kyrkoherde i Kumla. Under I8I2 och I8I3 gav han ut ett par häften med titeln"Prof-Psalmer" tillsammans med Johan Olof Wallin (I779-I839). Någon gång under sitt klerikala diktande har han känt ett behov av en patriotisk insats i den för landet avgörande striden mot Napoleons herravälde i Europa. Kanske förklaras den smått naiva och troskyldiga religiösa tonen i beväringsvisan av den då aktuella diktningen i kyrkans tjänst.

Krigsvisa nummer två är en hela sexton strofer lång sångtext med titeln "Fält-Wisa efter landstigningen i Pommern". Så här lyder de två första stroferna:

Nu i Guds namn stå wi här,

Långt från egna skär.

Detta land skall se wårt mod,

Kanske ock wårt blod.

Gerna ge wi det, hwar man,

När oss Carl för an.

För en rättwis sak han slåss,

Och är sjelf bland oss.

De första versraderna appellerar till soldaternas belägenhet, långt hemifrån och med farliga och riskfulla fältslag framför sig. Men så följer en tanke på befälhavaren Karl Johan och den "sak" han slåss för, nationens bästa.

Därpå levereras en hånfull attack på "fransoserna", den franska fiendehären, och framför allt dess ledare, Napoleon. Kärnan i det hatiska utfallet refererar till kejsarens svar till den svenske kungen efter freden i Tilsit 1807, nämligen uppmaningen att kungen skulle vända sig till den ryske kejsaren och det efter att Napoleon hade prisgivit Sverige åt kejsarens godtycke. Fördragen i Tilsit resulterade i Rysslands överfall på Finland I808 och Sveriges förlust av sin östra rikshalva. Finland var Franzéns hemland.

ämbetsman och var redan i dessa unga år en av Gustaf af Wetterstedts (I776-I837), chef för krigskansliet och hovkansler, närmaste män under kriget i Tyskland. Så småningom skulle Hartmansdorff bli af Wetterstedts efterträdare som hovkansler och också konservatismens ledande kraft i svensk politik. 
Den fjärde och femte strofen trumpetar ut ett tydligt napoleonhat till uppbyggelse av soldaternas stridsmoral, făr man förmoda. Det delades troligen av författaren själv med tanke på de personliga följderna för Finlandsfödde Franzén: livslång landsflykt i Sverige. En tillfogad försoningsgest i sista versraden avslöjar en kyrkans man:

Falske! bäst du gaf din hand,

Tog du bort wårt land.

Ej en tumsbredd tar du mer,

Sen du oss här ser.

Endast landet plundra ut,

Wille du till slut.

Guds wälsignelse är qwar,

Trots ditt rån, barbar! $!^{11}$

Sedan följer några strofer som välvilligt prisar tyskarnas vänskapliga bemötande av de svenska soldaterna. De bjuder"Swensken bord och tak, / Mellan wapnens brak." Sedan är det dags för den historiska återblicken med anknytning till Gustav II Adolfs framgångar under I60o-talet i religionskrigens Tyskland. Även Karl XII berörs med sina "gossar blå". Slutligen skall Napoleon störtas, siar textförfattaren, även om den avgörande uppgörelsen återstår vid den här tidpunkten:

Men Guds finger, redan röjdt,
Wisar, att fast dröjdt,

II. Svenskarnas komplicerade förhållningssätt till Napoleon, som pendlar mellan hat och beundran, formuleras inför en internationell publik av historiken Lars Ericson på följande sätt: "Crown Prince Karl Johan had refrained, during the Russian campaign of Napoleon in I812, from exploiting the weakness of Russia to reconquer Finland. This was a fact that gave rise to widespread bitterness, particularly within a field army forced to fight against the admired French alongside its former mortal enemies. The general feeling of discontent within the army changed for the better only due to the terms of the Treaty of Kiel and the acquisition of Norway. The loss of Finland was still deeply felt, as was the aversion to the Russians, but Swedish politics and the ongoing war were given a new meaning", Lars Ericson, "The War with Norway in I8I4 and the Occupation of I8I4-I8I5", Johan Engström (ed.), Between The Imperial Eagles. Sweden's Armed Forces during the Revolutionary and Napoleonic Wars I780-I820, Meddelande/Armémuseum, Armémusei vänner I7 (1998-1999), Stockholm: Army Museum 2000, s. 439. 
Oundwikligt stunda skall

Öfvermodets fall.

I sista strofen sammanfattar diktaren det övergripande målet för kriget: en efterlängtad fred, "frid". Han vänder sig till soldaterna i fält inför de stundande drabbningarna och understryker den historiska betydelsen av deras insatser under denna avgörande tid:

Bröder! för en werldsdels frid,

Är wår ädla strid.

Bröder! efterwerlden än,

Skall wälsigna den.

Så var det dags att efter det framgångsrika slaget i Dennewitz, där fransmännen under marskalk Michel Ney fick ta till flykten, tåga till Leipzig och möta Napoleon själv. Där hade kejsaren grupperat huvuddelen av sina styrkor. I den tredje dikten, med titeln inne i texthäftet "Sång öfwer slaget wid Jüterbock" med underrubriken "(Författad under Tåget till Leipzig.)", beskrivs krigssituationen. En hel del namn på framgångsrika befälhavare nämns i olika situationer. Den litterära nivån är betydligt högre och mer utarbetad än i de två första sångerna. Dikten är dessutom längre, hela 40 strofer, men avkortad i följande tryck i Skaldestycken II I828. ${ }^{12}$

Första strofen inleds på ett anslående sätt, så anslående att första raden har fått fungera som titel till dikten i andra tryck från kriget och tiden därefter:

Som örnen öfwer sjö och land,

Med stolta wingar far:

Så flyg, min sång, kring Bältens strand,

Högt swingande och snar.

Redan i följande strof lovordas segern vid Dennewitz. Kyrkoherde Franzén manar sin läsare att vända sin tacksamhet till Gud:

I2. Franzén, Skaldestycken, s.307-310. Nedan citeras texten efter första trycket I8I3. 
Och sig bland häpna skaror ner,

Med segrens glada bud;

Och der du Templen öppna ser,

Träd in och lofwa Gud.

Följande strof utandas en suck av lättnad. Herrens vrede är förbi liksom det gissel han har slagit världen med. Tankarna går tillbaka i tiden till den farliga situation som uppstått efter Napoleons seger vid Dresden och kejsarens plan att erövra Berlin för att sedan ta ett ”jättesteg mot Wien":

Men, si! ett folk, som han försmått,

Här står från Nordens wik.

Dess arm ett hufwud saknat blott,

Att blifwa fädrens lik.

Det fans, det hufwudet: se der!

Odödligt ren förut,

Det i sin blick en stråle bär,

Som bådar wåldets slut.

Så var Karl Johan på plats, han som kom "med jordens hopp”. Nu minskar Napoleons storhet medan den växer "hos Swerges Kungason!". Kronprinsen sitter trygg i sitt högkvarter i Rabenstein och ser den franska härens rygg,"som kom med öfwermod":

Men wek i hast med skräck och skam;

Ty, som ett åskmoln far,

Så red en tropp med dunder fram,

Och Swensk den troppen war.

Därefter skildras slaget vid Dennewitz. Den ena franska styrkan efter den andra blir besegrad, men Karl Johan sitter i Rabenstein och tänker bland annat på sin forne vapenbroder Moreau, som sårats dödligt i slaget vid Dresden några veckor tidigare. Han samlar sina tankar och utbrister: 
"Ej skall Europa bli en träl,

Ej ljuset slockna ut!"

Så war i Hjeltens höga själ

Det heliga beslut.

Han överväger sina planer för den närmaste tiden, de europeiska folkens framtid står på spel. Han samlar sina närmaste officerare och formulerar sitt beslut:

Straxt lugn igen, han kring sig böd

En krets af Hjeltar stå.

"Jag will ha slut på folkens nöd,

Jag will till Leipzig gå.”

Så Hjelten sade: Stedingk stod,

Med silfwerhjessan höjd,

Och Adlercreutz brann het af mod,

Och Tawast log förnöjd;

Och Löfwenhjelm tog på sitt swärd;

Och alla, hög och låg,

Ren tänkte på en efterwerld,

Som sjunger detta tåg.

Sedan avslutas dikten med en skildring av själva striden. Karl Johan har en inre syn: Gustav II Adolf följer striden från sin himmel. ${ }^{13}$ Han ser med gillande blick på Blücher som anför den preussiska armén, han ser med samma gillande ett par andra befälhavares strid, men med oro på Tauentzien som blev attackerad av polskt kavalleri från den franska sidan. ${ }^{14}$ Karl Johan ingriper och till sist får de franska styrkorna under befälhavaren Michel Ney ta till flykten:

13. Franzén hade ett starkt intresse för den svenska historien. En av hans favoritgestalter var just Gustav II Adolf om vilken han författade ett ej slutfört drama, Gustaf Adolph i Tyskland.

I4. Friedrich Bogislav von Tauentzien (I760-1824) förde befäl över den ena av två preussiska armékårer i nordarmén under Karl Johan. 
Der, på hwar sida ringad om,

Han oförfärad stod,

Tills Carl med sina Swenskar kom,

Liksom en Fjellens flod;

Hwars forss, ur isens brutna dam,

Sig störtar i en dal,

Och omotståndlig rusar fram,

Bland hjordar utan tal.

Som dessa, under strömmens fart,

Förswinna här och der:

Så ses blott flydda flockar snart,

O Ney! af all din här.

I de sista tre stroferna anknyter diktaren på nytt till Gustav II Adolf, men fältmarskalken och överbefälhavaren Lennart Torstenson, som i slutskedet av 30-åriga kriget ledde fälttåget mot Danmark I643-I644, får sista "ordet".

Lyft, Torstenson, din krönta lock,

Och nicka från din mull.

Och skaka skölden på din grift,

Att det ger fjerran dån,

Och eldar, till en stor bedrift,

Hwar Fosterlandets son.

Sista "ordet" ljuder från historien, den segerrike Torstenson nickar gillande. Den avsedda publiken, soldaterna i fält och anhöriga hemma, förstår stundens allvar och storheten i segern vid Dennewitz och den ära som är förbunden med att ha deltagit i något som skall ge eko i framtidens historieskrivning. ${ }^{15}$

15. Franzéns soldatvisor kom att bli en inspirationskälla för senare krigslyrik. I Johan Ludvig Runebergs "Soldatgossen” i Fänrik Ståls sägner II möter liknande käcka, oförskräckta patriotiska förväntningar inför soldatlivet som i "En Afskedssång". Se vidare Samlade skrifter av Johan Ludvig Runeberg, under redaktion av Johan Wrede och Tore Wretö, fortonde delen. Kommentar till Fänrik Stäls sägner, utg. av 
Vi återvänder till maj I8I3 och tiden för Karl Johans resa till Rügen och Stralsund. Då utspelade sig nämligen ett smärre drama. Kronprinsens lärare i svenska språket, tidningsmannen och diktaren Pehr Adam Wallmark (I777-I858), föll offer för kronprinsens vrede. Detta skulle i förlängningen leda till att en nådedikt, eller sångtext, såg dagens ljus i självaste Riddarhuset författad av en stukad supplikant. Vad hade hänt?

\section{STOCKHOLM}

Pehr Adam Wallmark var redaktör för Journal för Litteraturen och Theatern sedan den $\mathrm{I} 7$ juli $\mathrm{r} 809$ då tidningens första nummer utkom. Namnet hade valts för att betona att tidningens avsikt var att verka på det litterära och kulturella fältet och på så vis dämpa censurens närgångna uppmärksamhet under Gustav IV Adolfs regeringstid, något som emellertid hade upphört att vara aktuellt efter statsvälvningen den 13 mars I809.

Det hade gått några år sedan starten och tanken att tidningen skulle vara ett renodlat kulturorgan hade övergivits. Det kan man konstatera när man slår upp nr Io3 den 6 maj I8I3. Dagspolitiken hade fătt ta plats, kanske svårt att undvika i en tid av intensiv politisk aktivitet och med en hel del nya tidningar som kommit till efter den islossning för det fria ordet som följde på statsvälvningen. En sådan tidning var Nya Skandinaven.

Wallmark omfattade principen att hålla Journal för Litteraturen och Theatern öppen för insända artiklar av olika slag, blott med undantag för sådant som stred mot hans etiska och principiella grunduppfattning. Således låter han trycka i ovannämnda nummer en insändare som undertecknats "N** nära Stockholm d. 5 Maj I8I3. Hatare af Lättsinnighet i wigtiga ämnen.", med rubriken "Till Utgifwaren. M.H." ${ }^{\prime 6}$ Av

Johan Wrede, Helena Solstrand och Ulla Terling Hasán, Svenska författare utg. av Svenska Vitterhetssamfundet XVI, Stockholm: Svenska Vitterhetssamfundet I987, s. 307-309; Ett flertal befälspersoner som förekommer i "Sång öfwer slaget wid Jüterbock" återfinns också på flera ställen i Fänrik Ståls sägner I (I848) och II (r86o): t.ex. "Sandels", "Löjtnant Zidén”, "Fältmarskalken", ”Adlercreutz". Att levandegöra situationen med namn och miljö ger konkretion och närvaro i berättelsen. Jfr Lundström, Frans Michael Franzén, s. $44 \mathrm{f}$.

I6. "Till Utgifwaren. M.H.", Journal för Litteraturen och Theatern, nr I03, 6/5 I813. 
första stycket förstår läsaren att ämnet berör det faktum att en tidning i huvudstaden hade röjt statshemligheter på ett överraskande sätt.

Jag har just nu erhållit N:o 77 af Nya Skandinaven. Se der M.H. en mängd nyheter, hwarom man wäl talat sins imellan, men som man icke wäntat att så snart och framför allt icke på detta sätt få se lagda för en öppen dag. Jag ber Er meddela följande wälmenta betänkligheter öfwer dylika kungöranden, oaktadt jag förutser, att det torde uttydas såsom en afundsjuka för det ej ert Blad gjorts till Depositär af så wigtiga underrättelser, i en tid då det werkeligen kunde synas, som Statens hemligheter aldrahälst förwarades i offenteliga Tidningar.

Därefter följer ett resonemang om berättigade och oberättigade krig med några slående exempel, vilket avslutas med att författaren vill uppehålla sig vid "behörigheten av sjelfwa underrättelserna". Sedan frågar han sig huruvida dessa är "kungjorda med Regeringens tillstånd". Han frågar sig också huruvida Nya Skandinaven är ett mer officiellt blad än Wallmarks tidning eftersom regeringen låter den meddela politiska nyheter. Här kan inflikas att Wallmark, i egenskap av kronprinsens lärare, bör ha ansetts stå närmare kronprinsen än utgivaren av Nya Skandinaven, vilket förklarar något av författarens häpnad över saken. Han uttrycker sig ironiskt mot Wallmark som utgivare av Journal för Litteraturen och Theatern.

Nya Skandinavens utgivare var Carl August Grevesmöhlen (I754I823). ${ }^{17}$ Grevesmöhlen hade ställt sig bakom bondeståndets kamp mot adelns och prästeståndets försök att bevara sina gamla privilegier under riksdagen I809. Bondeståndet önskade utkräva ansvar för de ämbetsmän som ännu var kvar i tjänst från Gustav IV Adolfs regeringstid. Grevesmöhlen utgav anonymt en skrift i vilken han skisserade hur en folkets revolution skulle gå till med mönster från den franska revolutionen. Han försvarar Robespierres radikala politik. Litteraturvetaren Kurt Johannesson sammanfattar hans roll under

Clara Wallmark, Pebr Adam Wallmark. En tidsbild från adertonhundratalets första bälft, Stockholm: Ivar Haeggströms Boktr. \& Bokförlags A.B. I9I4, s. 72, noterar att Wallmark inte hade någon anledning att tveka att ta in insändaren eftersom han kände dess författare som en person "som var prinsen ganska tillgifven".

I7. Se vidare Höjer, Carl XIV Johan. Kronprinstiden, s. I64 f. 
riksdagen: "Grevesmöhlen hade blivit en politisk maktfaktor." ${ }^{18} \mathrm{Un}$ der åren före I8I3 gav han ut tidningar såsom Åskådaren (I8II-I8I2), Trompeten (1812), Skandinaven (1812) och Nya Skandinaven (1812-I813). De två sistnämnda anses syfta till att stödja Karl Johans politik. Grevesmöhlen hade under riksdagen i8ro arbetat för Bernadottes kandidatur. Under riksdagen 1812 kom Grevesmöhlen att ogilla inskränkningarna av tryckfriheten i TF I812 och drabbades därmed av kronprinsens missnöje. Året därpå kom Karl Johan emellertid att utnyttja Grevesmöhlen som agent i pressen med direktförbindelse till hovkanslern. ${ }^{19}$ Det är tveksamt om Wallmark uppfattade Grevesmöhlens ställning rätt.

Men vad gällde saken mera i detalj? Låt oss kasta en blick på den insända artikeln i den sistnämnda tidningen, vars fullständiga namn är Nya Skandinaven. Veckoskrift för Medborgares nytta och nöje. Artikeln fyller hela det fyrsidiga nummer 77 av tidningen. Numret utkom i Stockholm den 3 maj I813. ${ }^{20}$ Vilka är de statens hemligheter som "förwarades" $i$ offentliga tidningar?

Artikeln inleds med reflektioner om när krig enligt folkrätten är berättigat. Ett exempel är då det föreligger ett geografiskt lämpligt läge mellan länder, "och genom hvilkas införlifvande med hvarandra, säkerheten för anfall ökas och freden således göres varaktigare". Kronprinsen prisas utan namns nämnande:

[...] den Stora och ovanliga Man, som en mild Försyn skänkt Svea Land $[\ldots]$ har insett att besittningen af Norrige är den enda utväg att återgifva åt Sverige den gräns, hvilken sjelfva naturen synes hafva utstakat för att göra tvenne till seder och språk så öfverensstämmande Nationer till ett enda gemensamt Folk under en och samma Spira.

I8. Kurt Johannesson,"Det fria ordets martyrer", Kurt Johannesson, Eric Johannesson, Björn Meidal, Jan Stenkvist, Heroer på offentlighetens scen. Politiker och publicister $i$ Sverige 1809-1914, Stockholm: Tidens förlag 1987, s. 29.

19. Höjer, Carl XIV Johan. Kronprinstiden, s. I33 f.

20. Insändarens rubrik är "Reflexioner om Krig i allmänhet och om våra närvarande rustningar", Nya Skandinaven. Veckotidskrift for Medborgares nytta och nöje, Stockholm: Tryckt hos Carl Delén 3/5 I8I3. 
Några rader längre ned i texten avslöjar författaren att han har kännedom om fördraget i Åbo och om att Sverige därmed hade lämnat kravet på återtagande av Finland:

Våre Bundsförvandter, Ryssland, England och Preussen hafva också garanterat Sverige besittningen af Norrige och begge dessa Rikens förening, hvarigenom den Skandinaviska half-ön vinner styrka och anseende bland Europas Makter.

Efter denna garantie hade vår Regering det hopp, att Norriges afträdande skulle kunna vinnas genom fredliga negotiationer med Konungen i Dannemark, och Krigets olyckor således kunna undvikas; $[\ldots]$.

Sverige rustade för strider på kontinenten för"Sveriges ära och mänsklighetens rätt”. Att ett syfte var att fortsätta mot Danmark och anfalla landet på dansk jord uttrycks fullständigt klart:

Svenska tropparne komma att inrycka i någon af Dannemarks besittningar på andra sidan om Sundet, för att derigenom tvinga Konungen i Dannemark till fredliga tänkesätt, och till ett godvilligt afträdande af Norrige, [...].

Det bör ha varit passager som dessa i Nya Skandinaven som föranledde "Hatare af Lättsinnighet i wigtiga ämnen" att i Wallmarks tidning ge uttryck för sina reaktioner.

Det var emellertid artikeln i Journal för Litteraturen och Theatern som fick kronprins Karl Johan att vredgas när han nåddes av information om insändarväxlingen i Stockholmspressen. ${ }^{21}$ Straffet var hårt och utdelades blixtsnabbt. Wallmark redovisar själv ämnet, när han behandlar det i sin självbiografi ${ }^{22}$, visserligen skriven långt efter att händelserna hade utspelat sig. Men han hade haft god tid på sig att

2I. Jfr Villstrand, Furstar och folk i Åbo I8I2, s. I27-I29. Villstrand redogör för situationen och i detta sammanhang nämner han även en inlaga från kronprinsen till statsrådet i vilken han t.o.m. hotar att avgå som en följd av konflikten med Wallmark.

22. Wallmarks självbiografiska artikel,"Pehr Adolf [sic] Wallmark", Biographiskt lexicon öfver namnkunnige svenska män, nittonde delen, Uppsala: Wahlström et C. På N.M. Lindhs förlag $185^{2}$, s. 375 . 
tänka igenom saken i lugn och ro på sin lilla gård i Kungsör, dit han hade dragit sig tillbaka efter ett långt liv i publicistikens tjänst.

Den I4 Maj ankom H.K.H:s Adjutant, Majoren Påhlman, som curir från H.K.H. med ett bref till H.M. Konungen, som i de strängaste ordalag lärer yrkat Journalens indragning och med ett annat till Excellencen v. Engeström med befallning att förklara mig H.K.H:s onåd och förlusten af den pension jag som H.K.H:s och H.K.H. Arfprinsens f.d. lärare i svenska språket innehade. Indragningen skedde d. I7 Maj ı8г3 [...].

Kronprinsens onåd bör ha varit något av en chock för Wallmark. Den drabbade honom troligen helt utan förvarning. Ett personligt slag, men hur förklarar han sitt misstag att införa artikeln? Några rader längre ned i hans redovisning läser man:

Jag lät förleda mig af den insända artikelns icke blott juridiska oförgriplighet, men äfven af dess försvar för skrifven lag [...]. Men jag hade bordt erinra mig, att för stora män framtiden ofta slår upp sin förseglade bok, och att förutsägelsen således möjligen kunde härröra från den, som deri redan läst, att han skulle uppfylla den. Jag kände dessutom, af egen obehaglig erfarenhet, att Grevesmöhlen hade gynnare inom H.K. Höghets närmaste omgifning, genom hvilka han kunnat underställa sin uppsats H.K. Höghets pröfning och få tillstånd till dess införande i sin tidning. ${ }^{23}$

I anslutning till denna skildring av sitt personliga och yrkesmässiga haveri prisar han sig ändå lycklig att ha haft en betydelsefull beskyddare, nämligen excellensen Gustaf Löwenhielm. Redan i juli I8I3 berättade denne i ett brev till Wallmark att han hade talat med kronprinsen till förmån för sin protegé och hade fått löfte om att kronprinsen skulle ompröva sin inställning till Wallmark "efter första vunna batalj”. Wallmark fortsätter: "Tillfälle dertill yppades ej för-

23. Ibid., s. 375 f. En kritisk granskning av konflikten mellan kronprinsen och Wallmarki ett utrikespolitiskt perspektiv, se Hans Forssell, Gustaf af Wetterstedt. Minnesteckning forfattad for Svenska Akademien af Hans Forsell, Svenska Akademiens Handlingar, Stockholm: Svenska Akademien i889, s. 357-362. 
rän efter den första i Holstein vunna bataljen.” Slaget vid Bornhöft i Holstein ägde rum den 7 december I813. Wallmark skriver vidare: "[I] ett bref dateradt Cöln d. I8 Febr. I8I4, underrättade mig omsider den ädle gynnaren, att, på hans bemedling, H.K.H. återskänkt mig allt hvad jag förlorat, och deribland det för mig dyrbaraste, sin fordna nåd.**” Den avslutande noten [**] upplyser om att hans tidning, nu Allmänna Journalen, redan den $\mathrm{I}_{4}$ juni $\mathrm{I}_{8} \mathrm{I}_{3}$ hade börjat utges under detta nya namn av hans vän och medarbetare Per Adolf Granberg (I770-I84I) och att tryckeripersonalen hade fortsatt arbetet. ${ }^{24}$

Men vi återgår till tiden mellan onådens inträdande den I7 maj I8I3 och dess upphörande den I8 februari I8I4. Wallmark nöjde sig inte med att låta Gustaf Löwenhielm sörja för hans framtid och med att få förlåtelse av höga vederbörande. Han drar också själv ett strå till stacken.

I Allmänna Journalen införde Wallmark i nr 130 den $\mathrm{i} 2$ november I8I3 en dikt, eller snarare en sångtext, riktad till Karl Johan: "Verser till Hans Kongl. Höghet Kronprinsen, i anledning af de förenade Arméernas Seger vid Leipzig*." Noten [*] lyder: "Afsjungne af Herr Karsten vid Koncerten på Riddarhuset d. Ir:te November. Musiken, komponerad af Herr Berwald." ${ }^{25}$ Texten salufördes också som trycksak om tre sidor. ${ }^{26}$

24. Wallmark, "Pehr Adolf [sic] Wallmark", s. 376.

25. Med "Herr Berwald" avses Johan Fredrik Berwald (I787-I86r), dirigent, violinist och kompositör. Berwald var en flitig tonsättare med ett flertal kompositioner för ceremonier kring Karl Johan, prins Oscar m.fl. inom kungafamiljen. Han genomförde en sista del av sin utbildning i S:t Petersburg och kom tillbaka till Stockholm I8r2. Kompositionen "Segersång öfver slaget vid Leipzig för tenor" (I8I3) trycktes inte i samtiden och manuskriptet har inte återfunnits. Julius Rabe, ”Johan Fredrik Berwald", Svenskt biografiskt lexikon. Fjärde bandet, Stockholm: Albert Bonniers förlag 1924, s. 27-3r. J. F. Berwalds kusin Franz Berwald (I796-1868) har komponerat ett verk om samma tema, nämligen orkesterstycket "Slaget vid Leipzig". Christopher Christian Karsten (I756-1827) var operasångare (tenor/baryton) och en av den gustavianska tidens mest berömda artister.

26. [Pehr Adam Wallmark], Verser till Hans Kongl. Höghet Kronprinsen, i anledning af de förenade Arméernas Seger vid Leipzig, Stockholm: Elméns och Granbergs Tryckeri I8I3. Trycken är likalydande. Författarnamn saknas i denna trycksak. 
Slaget vid Leipzig utkämpades som nämnt den I6-I9 oktober I8I3. På mindre än en månad hade information om segern nått Stockholm, Wallmark hunnit författa sin panegyriska text, Johan Fredrik Berwald komponera musik till den samt engagera sig i den kommande hyllningskonserten. De båda herrarna bör ha arbetat under största möjliga tidspress under ett par, tre hektiska veckor.

Hell Dig, som höjt på stridens bana

Vid CARLS baner Gustafvers glaf,

Att inom nya dammar mana

Det blodiga Förtryckets haf;

Som, segrande, på en gång vakar

För verldens lugn och för Ditt lands,

Der, från Din ljusa char, du skakar

Kring Sveas strand dess fordna glans.

O Rhen! från Alpens höga klyfta, Se än en CARLS och Segerns Son

Af Elbens skullra bojan lyfta,

Och gläd dig med fördubbladt dån!

Snart skall du sjelf, förvånad, skölja

Den strand Hans segrar gjorde fri,

Och evigt se din stolta bölja

Ett värn mot Våld och Tyranni.

På Leipzigs Marathonska slätter,

Så frejdade af Göthers mod,

Än Friheten sin lager sätter

Och vattnar den med Gallers blod;

Snart, vårdad af CARL JOHANS händer,

Den famna skall blott fria tjäll

Och Frias lof på Tajos stränder

Besvaras ifrån Nordens fjell.

Wallmark inleder sångtexten med en högstämd hälsningsfras och dedikation med anknytning till landets konung Carl XIII och till historien, "Gustafvers glaf”, det vill säga ett långt vapen, likt en lans, som kanske främst associeras med Gustav II Adolf och hans trupper som stridit på samma fält där nu de nya striderna hade utkämpats. 
Kronprinsen utmanade förtrycket, Napoleon och hans trupper, segrade och vakade nu över såväl världsfred som sitt eget lands lugn. Strofen avslutas med en panegyrisk förhöjning. Från sin ljusa "char", vagn, överskådar han sitt land och återger det dess forna glans. ${ }^{27} \mathrm{Han}$ har återställt landets ära.

Följande strof inleds också med en dedikation,"O Rhen!”. Floden personifieras och får betrakta händelsernas gång. Än en gång får den se floden Elbe och norra Tyskland befrias av en svensk härförare och se sig som en gräns och ett värn mot förtryck utifrån, en upprepning av erfarenheter från förr. Den historiska aspekten löper genom dikten.

I den tredje och avslutande strofen jämställs det nyss utkämpade slaget vid Leipzig med det vid Marathon 490 f.Kr., ett slag som för eftervärlden kom att symbolisera ett litet lands kamp för självständighet gentemot en stormakt. Här på Leipzigs slätter har nu Friheten planterat fredens och ärans lagerträd vattnat med blod från fallna franska soldater. Fredens lagerträd vårdas av Karl Johan, vars namn nämns först här. Strofen avslutas med en förhöjning av hjälten. Fria människor från Tajos stränder ända till Nordens fjäll lovprisar honom. Tajo eller Tejo är den längsta floden på Pyreneiska halvön, flyter västerut och mynnar ut i närheten av Lissabon. Karl Johan har befriat Europas folk från söder till norr från våld och krig. Han vårdar världsfreden.

Wallmark har valt den fyrtaktiga jamben som versform. Kvinnligt och manligt rim tillämpas växelvis. Alexandrinen, den sextaktiga jambiska versen, var sedan I7oo-talet den vanliga versformen för hjältedikt. Möjligen har Wallmark valt den snabbare fyrtaktiga versformen med tanke på att dikten skulle tonsättas och sjungas, kanske från första början i samarbete med kompositören.

Versen förefaller att flyta lätt och ledigt trots att textens innehåll kan kännas krävande med metaforer, förhöjningar och personifikationer. Wallmark har presenterat en panegyrisk text i harmoni med klassiska mönster. Huruvida han vann framgång $\mathrm{i}$ kronprinsens ögon och således snabbare skulle få tillbaka sina uppdrag samt kronprinsens

27. Solmetaforen var en vanlig typ av förhöjning vid skildring av en kung under det kungliga enväldets tid. 
förtroende, är emellertid höljt i dunkel. Det skulle fortfarande krävas danska arméns nederlag vid den första bataljen, något som ju inträffade några veckor senare. Men först en bit in på I8I4 skulle saken vara ur världen och livet gestalta sig som vanligt för den skakade poeten och publicisten. Man får förmoda att Wallmark led en viss ekonomisk skada, men han har själv yttrat att det förnyade förtroendet från kronprinsens sida var den avgörande frågan för honom. ${ }^{28}$

Till sist skall konserten och musiken till "Segersång öfver slaget vid Leipzig" beröras. Verket finns upptaget i Berwalds egenhändiga verkförteckning förmedlad av Ny tidning för musik 1856: "I8ı3 [...] 23) 'Segersång öfver slaget vid Leipzig', för tenor-röst och orkester. (Sjungen af Karsten vid en af komponisten gifven koncert å Riddarhuset)" ${ }^{29}$ I Berwalds självbiografiska anteckningar "Utur mitt lif" skriver tonsättaren några rader om konserten. Alldeles innan han avreste till England gav han den såsom en avskedskonsert:

och som just då Carl Johan vunnit den stora segern vid Leipzig och hela Stockholm var i förtjusning, componerade jag för tillfället en Segersång, hvartill orden skrefs av Wallmark och hvilken afsjöngs på ofvan-nämnda Concert af den utmärkte sångaren Karsten. ${ }^{30}$

Stämningen bland stockholmarna var alltså "förtjusning”. En seger på slagfältet hade inträffat efter så många år av nederlag och förnedring och stockholmarna gav uttryck för lättnad och glädje. Konserten var säkerligen en manifestation av nationell betydelse, en god jordmån för en panegyrisk sångtext sjungen av tidens mest kända sångare.

28. Wallmark, "Pehr Adolf [sic] Wallmark", s. 376.

29. Ny tidning for musik, Stockholm: Tryckt hos Isaac Marcus 1856:I3. Har ej försetts med notisen "Tryckt". Förteckningen med kort inledning har undertecknats med signaturen Bmn (Boman, Pehr Conrad, 1804-I86I). Den har rubriken "Förteckning på Johan Berwalds kompositioner".

30. Berwalds anteckningar"Utur mitt lif" (autogr.), Handskr. 332 Musik- och Teaterbiblioteket, Stockholm; Adolf Lindgren skriver i en artikel om Berwald i Adolf Lindgren, Svenske hofkapellmästare I782-I882. Ett bidrag till Operahusets hundraårsminne, Stockholm: Huss \& Beer I882, s. 89, och kallar där kompositionen "en hymn öfver den nyligen vunna segern vid Leipzig". 
I Allgemeine musikalische Zeitung $\mathrm{nr} 5$ I8I4 den 2 februari under rubriken "Nachrichten" får man veta vilka andra verk som spelades vid konserten samt läsa följande kortfattade kommentarer:

Stockholm. Monat November. Den irten gab Hr.J.F. Berwald Concert, wobey Folgendes gegeben wurde: Ouverture, ziemlich - ViolinConcert, comp. und gespielt von Hrn. Berwald, - sehr gut - Scene von Spontini, von Hrn. Karsten vortrefflich gesungen. - Beethovens Septett schon mehrere Male gegeben, von Hrn. Berwald (Violin) Crusell (Clarinette) Hirschfeldt, (Horn) Conr. Preumayr, (Fagott) Askergren, (Viola) Megelin, (Violoncell) und Wirthe (Bass) gut vorgetragen. - Einige schwedische National-Lieder, mit Variationen für Violin, von Hrn. Berwald comp. und gespielt. - Cavatina zur Feyer des Sieges bey Leipzig von Hrn Berwald componirt und von Hrn. Karsten gesungen. ${ }^{31}$

Kanske kan benämningen i den tyska tidningen såsom "Cavatina” ge någon ledtråd om hur musiken kan ha gestaltat sig. En Cavatina är en aria i enkel stil. Den har också av Berwalds biograf Adolf Lindgren karaktäriserats som en "hymn". ${ }^{32}$ Man kan i varje fall konstatera att den för publiken välkända solorösten ackompanjerades av orkester.

\section{FINSPÅNG}

Underrättelserna om segern vid Leipzig firades med "förtjusning" och festligheter i huvudstaden. Och i landsorten, vad kunde hända där? En dag i november hölls en högtidlig gudstjänst i Finspångs kyrka med anledning av den lyckliga nyheten. Ett musikverk med text för recitatör, kör och solister hade författats på orten. Allmänna Journalen förmedlar texten i nr 153 den 9 december I8I3. Rubriken skvallrar om att dagen för framförandet inte var känd i Stockholm vid tidpunkten för dess offentliggörande. Den lyder: "Ord till Musiken wid Te Deum i Finspongs Kyrka d. [tomrum] November I8I3, författade af

31. "Nachrichten", Allgemeine musikalische Zeitung, nr 5, Leipzig: Breitkopf und Härtel I8I4, s. 88.

32. Lindgren, Svenske hofkapellmästare, s. 89. 
Sockne-Presten." Framförandet skedde med andra ord samma månad som konserten på Riddarhuset i Stockholm. ${ }^{33}$

Gudstjänsten i fråga var alltså en tacksägelsegudstjänst med anledning av segern vid Leipzig. Sockenprästens kantattext är riktad till Gud som tacksägelse med anledning av segern, samt även riktad till kronprinsen som var föremål för själva hyllningen. Fördelningen mellan tacksägelse respektive hyllning framgår av textens innehåll. Kantattexten återspeglar rikhaltigt känslor och stämningar kring den viktiga nyheten. Växlingen mellan olika stämmor, arior, duor, recitativ och körer är livlig. Församlingen bör ha haft god möjlighet att följa framförandet med intresse. Huruvida kompositionen inleddes med ett instrumentalt avsnitt går inte att veta, men man kan anta att så var fallet.

Den textbaserade delen av kompositionen inleds i varje fall med en pampig Aria Andante Maestoso, en röst som framför de fyra första versraderna majestätiskt i lugnt medeltempo, och man kan tänka sig att den ackompanjerande musiken framfördes som en mäktig bakgrund. Dessa fyra versrader refererar först och främst till Tyskland, där själva slaget hade utkämpats. Därifrån har hörts "fröjdeskall”, glada utrop: har verkligen en svensk besegrat den oövervinnelige Napoleon, har "åter", efter segern vid Dennewitz, en svensk härförare orsakat "Tyrannens" nederlag?

Från de Germanska fälten

Hwad nya fröjdeskall!

Har åter Swenska Hjelten

Beredt Tyrannens fall?

Det påföljande körpartiet svarar på solistens fråga och, förefaller det med tanke på blankraden, solisten fyller på med ett förtydligande: Gud har hört svenskarnas böner, hjälpt den svenska truppen och skyddat dess anförare, kronprinsen, vilket sammanfattas och repeteras i två versrader av kören.

33. En motsvarande hyllningsfest i Tyskmarks (trol. Töcksmarks) kyrka i Värmland redovisas i Norrköpings Tidningar, nr 105, 3I/I2 I8I3. Ceremonin ägde rum den 2I/II I8I3 med vokal- och instrumentalmusik, predikan, psalmsång och kanonsalvor samt insamling av medel till nyblivna soldatänkor vid Nordmarks kompani. 
Ja åter Swenska Hjelten

Beredt Tyrannens fall.

Gud hörde dina böner;

Det löfte, Swea! mins.

Gud bistått Dina söner

Och skyddat Swerges Prins.

Sedan följer ett recitativ, en röst sjunger eller talar och musiken, kan man tänka sig, ackompanjerar diskret. Texten flyter ut i beskrivande och starkt hyllande panegyriska metaforer. "Tideböckren", historieböckerna, kan knappast någonstans skildra liknande "ärofulla” dagar som de då slaget vid Leipzig ägde rum. De krigsdrabbade och plågade folken behöver inte längre beklaga sig sedan "Nordens Prins" kommit "med sitt dragna swärd" för att försvara "Nationerna" och trotsat naturens, "Elementens", hot. Med råd och hjältemod hade han slagit fiendens här till marken och erövrat folkens lovpris och förundran. "Hans röst”, hans befallningar, återger Europas folk deras frihet. Recitativet representerar en kommenterande mellandel i kompositionen.

Efter recitativet följer en Aria Larghetto, en solosång i modererat långsamt tempo. Två dagar av slaget skildras lyriskt: "Dagens Drott sin fackla släckte", solen har gått ned. Natten går till ända och förnyade krigshandlingar äger rum dagen därpå: många stupar i trakten av floden Saale ("Fann sin graf i Saales nejd") - som flyter mot norr genom Tyskland förbi Halle, strax nordväst om Leipzig till Elbe. Fältslagets verkliga förlopp skymtar fram.

I nästa strof som är en Ariette, en mindre aria i vismanér, skildras fienden, Napoleon, "Wåldswerkarn”. Han har envist trott på lyckans ynnest, men hans högmod sviks av henne - av lyckan, vilket gör segern så mycket större för motparten. Kören är tillbaka och repeterar sista frasen. Napoleon har kommit tillbaka efter nederlaget i Ryssland och tycks ha "återrest”, till livet återkallat, fallna soldater och anfallit Tyskland på nytt med nya trupper. Men förgäves, de nya trupperna störtas till marken av blixtrande kanoner. Sista versraden konstaterar kejsarens nederlag:"Och lagern från hans hjessa rycks." Den upprepas och präntas in av kören i ett kort inlägg. 
Så återkommer recitatören med en uppmaning till kejsar Napoleon, nu i slutfasen av sin maktutövning, att tänka på vem som sätter gränsen för hans anspråk. Svaret är: kronprins Karl Johan på slagfälten i Dennewitz och Leipzig.

Därpå följer en Aria Allegretto, ett solonummer i livligt tempo, som framställer Napoleons ogärningar i aggressiv ton. Hans angrepp på Svenska Pommern i januari I8I2, där han tog svenska soldater och officerare som krigsfångar, nämns med orden: "Dess stridsmän du i bojor slöt." Napoleon fick alltså vad han ville men begärde mer och mer. Hans leende mot svenskarna, "Skandinavens nöd", poängterar hans hänsynslöshet. Sockenprästen i Finspång tänker sannolikt på den gången då Napoleon uppmanade den svenska kungen att förlita sig på kejsar Alexander I efter freden i Tilsit I807 och den följande förlusten av Finland. En sentida läsare förstår vid läsningen av versrader som dessa något av den förbittring som den tidens svenskar bör ha burit med sig i sitt förhållande till kejsar Napoleon. Nu hade hämnden kommit, en tillfredsställelse kan utläsas här. Så även i den följande strofen som har beteckningen Duo, sång för två stämmor. Napoleon tilltalas direkt, i anklagande ton, och det nämns att han bröt sig in över Pommerns gräns. Som straff skall han drivas mot sin egen gräns som flykting och överges av sina egna, siar textförfattaren.

Sedan följer en Aria Andante, solosång i lugnt medeltempo, och anklagelserna växer: "We dig, du glömt att den Nation är stark / Som pligtens Bud gjort till sin lefnads wana". Svenskarnas överlägsna moral är något som Napoleon inte hade räknat med, svenskarna hade dessutom lärt sig att segra under Karl Johans ledning, "wid Ponte Corvos fana”.

I följande strof med beteckningen Allegro, hastigt tempo, når anklagelserna sin höjdpunkt. Napoleon kallas en "Förtryckare!" som bör frukta "hämdens bloss!". Han har smädat Gud, som har kallat svenskarna att rädda friheten, varpå kören har ett kort, temperamentsfullt inlägg: "Som ljungande skall hämnas oss."

Verket närmar sig sitt slut i en Aria Maestoso av samma karaktär som den inledande strofen. Triumfen formuleras i fraser som "segerrop", "Bruten är Tyrannens boja" och "Slutadt Rhenförbundets Krig". Rhenförbundet var ett förbund av syd- och västtyska furstar I806-I8I4 anslutet i en militärallians med Napoleons Frankrike. De folk som 
hjälten, Karl Johan, har återgivit friheten, uppmanas att hylla sin befriare.

Så till sist följer ett Recitatif och en avslutande Choeur vilka sammanfattar och tolkar slaget vid Leipzig. Svenska folket uppmanas att rikta sin tacksamhet till Gud som också skall bli Karl Johans borg och försvar i farans stund till sena ålderdomen. I den avslutande körversen uppmanas svenska folket att tacka sin Gud för den välsignelse som han visat det genom att strida på dess sida. $\mathrm{Nu}$ kan svenska folket som en följd av Guds nåd vänta på en trygg fred. Texten mynnar ut $\mathrm{i}$ en hyllning till fredstanken. Hämndmotivet och furstehyllningarna är avklarade, diktens sakrala dimension avslutar kantattexten, diktad för en tacksägelsegudstjänst över segern i slaget vid Leipzig i Finspångs kyrka en sen höstdag år I8I3:

Ja! O Gud! ditt folk sig gläder

Öfwer Din välsignelse.

Du har tänkt på wåra fäder,

Oss du ej skall öfwerge.

Nej, Du stridde på wår sida:

Segern kom af himlen ned;

Gud! wi af din nåd förbida

Snart en trygg och ljuflig fred.

Vem var då författaren till denna omfattande och välskrivna text? Tiden som stod till buds var väl så pressad som den hade varit i Stockholm för paret Wallmark-Berwald. Om man håller fast vid uppgiften "Sockne-Presten", vilka präster finns att välja på i Risinge pastorat som bruket tillhörde? Linköpings Stifts Herdaminne kan ge några ledtrådar. Tre komministrar, en brukspredikant och en prost ingår i de möjligas skara. ${ }^{34}$ Av dem tycks prosten ligga närmast till som tänkbar författare. Matthias Stenhammar (I766-I845) var prost i Risinge pastorat I799-I845. Under I790-talet var han ordinarie hovpredikant och särskilt ansvarig för den då omyndige Gustaf IV Adolfs andliga fostran. År 1797 utnämndes han till kyrkoherde i Risinge pastorat och blev

34. Linköpings Stifts Herdaminne, Tredje delen, Linköping: AB Östgöta Correspondentens boktryckeri i917, s. 668-687. 
sedan prost där två år senare. Stenhammar var ledamot av riksdagens prästestånd vid riksdagarna från I809 fram till ı823. Han var känd som en framstående talare med litterära intressen. Han erhöll pris av Svenska Akademien och som psalmdiktare fick han psalmer införda i den Wallinska psalmboken I8I9. ${ }^{35}$

Artikelförfattaren i Biographiskt Lexicon öfver namnkunnige svenska män, som avslutningsvis upplyser om att han varit personligen bekant med Stenhammar, skriver emellertid:"För poesi i högre mening kunde dock denne man svårligen ega något sinne: i umgänget sträf, torr och kärf, kunde han icke vara någon Sånggudinnornas gunstling." ${ }^{36}$ Stenhammar kunde i varje fall författa religiös lyrik och kanske har dessa upprymda dagar efter segern $\mathrm{i}$ Leipzig fått sånggudinnorna att lätta på prostens kärva sinne och släppt fram en temperamentsfull men disciplinerad lyriker.

\section{SLutord}

Man kan säga att det lyckosamma krigsåret I8I3 slutade först den I4 januari I8I4 med undertecknandet av fredstraktaten i Kiel. Där fastslogs att den danska kungen skulle överlämna Norge till den svenska kungen. I artikel IV läser man att Norge skall "hädanefter under full ägo och öfwerherrskap tillhöra Hans Maj:t Konungen af Swerige, och utgöra ett Konunga-Rike förenadt med Swerige." ${ }^{37}$ Därmed var I8I2 års politik slutförd - trodde man. Det skulle visa sig att norrmännen redan i februari protesterade och valde en egen kung - men det är en annan historia. ${ }^{38}$

I Sverige kom segern i Leipzig och freden i Kiel att firas med folkfester i stort och litet format. I Stockholm anordnades illuminationer med eldar i stora kärl. Marschaller ställdes upp på utvalda platser.

35. Andreas Tjerneld,"Stenhammar", Svenskt biografiskt lexikon, Häfte ı62, Stockholm: Edita 2008, s. 305-307.

36. "Stenhammar, Matthias", Biographiskt lexicon öfver namnkunnige svenska män, $\mathrm{I}_{5}$, Uppsala: Wahlström et C. I848, s. 331.

37. Kungliga Förordningar I814, Stockholm: Kungl. Tryckeriet I8I4.

38. Om diktningen kring den slutliga föreningen med Norge, se Krister Nordberg, "Förenom oss Scandier. Dikt och politik I8I4", Historiska och litteraturhistoriska studier 89, Skrifter utgivna av Svenska litteratursällskapet i Finland (SSLS) 789, Helsingfors: SLS 20I4, s. I35-I64. 
Byggnader smyckades och fester anordnades över hela staden i februari I8I4. Te Deum i Finspångs kyrka och de dånande kanonsalvorna vid Tyskmarks kyrka som ägde rum redan kring mitten av november I8I3 är exempel på det likafullt präktiga firandet i landsorten.

Kring ${ }_{25}$ Karl Johan-dikter har noterats för år I8I3, men betydligt fler bör kunna räknas in om en komplett inventering även av andra politiska tidsdikter skulle genomföras. ${ }^{39}$ Tanken i den här studien har varit att söka fånga något av den mentala atmosfären i landet genom att belysa stämningar och opinioner i poetisk form, spridda $\mathrm{i}$ vida läsekretsar, kring de dramatiska händelserna under det som blev Sveriges sista stora krigsinsats på främmande jord - eller åtminstone näst sista. Det korta kriget på några veckor i Norge sommaren I8I4 återstod, vilket skulle bli det sista före den långa fredsperiod som landet har fått uppleva sedan dess.

Det visar sig emellertid att varken den tillfredsställelse som segerdikterna vittnar om eller unionen med Norge var tillräckliga som ersättning för förlusten av Finland. Efter en paus på något tiotal år återkommer diktarna till denna djupt ingripande nationella förlust ännu under några decennier. ${ }^{40}$

39. Sven Almqvist, "Poetiska hyllningar till Carl Johan under kronprinstiden. Ett bibliografiskt utkast", Carl Johans forbundets handlingar 1985/I988, Uppsala: Almqvist \& Wiksell I989, s. IIO-II2. I förteckningen ingår också några dikter riktade till prins Oscar och kung Karl XIII.

40. Se Nordberg, Såret vill blöda ännu, s. 105-167. 